\title{
Dichoropetalum schottii: examination of the type specimen, distribution and comparison with $D$. carvifolium-chabraei (Apiaceae)
}

\author{
Eugene V. Kljuykov ${ }^{1 *}$, Tatiana A. Ostroumova ${ }^{1}$, Fabio Conti ${ }^{2}$, \\ Patricia M. Tilney ${ }^{3}$
}

\begin{abstract}
The lectotype and isolectotype specimens of Peucedanum schottii, based on plants originally cultivated in Cremenets Botanical Garden, have been studied in detail. The geographic provenance of the plants is unknown but they are identical to natural populations in Albania, Bosnia \& Herzegovina, Croatia, France, Greece, Italy, Montenegro and Serbia. The valid name for this plant is therefore Dichoropetalum schottii. It differs from a related species, D. carvifolium-chabraei, in having glabrous umbel rays, white (not yellow) petals, long styles and solitary secretory ducts in fruit valleculae.
\end{abstract}

Key words: Dichoropetalum, Peucedanum, nomenclature, anatomy, micromorphology.

Riassunto - Dichoropetalum schottii: esame del tipo, distribuzione e confronto con D. carvifolium-chabraei (Apiaceae).

Il lectotipo e l'isolectotipo di Peucedanum schottii, basati su piante originariamente coltivate nell'Orto Botanico di Cremenets, sono stati studiati approfonditamente. La provenienza geografica del campione è sconosciuta. Il tipo corrisponde alle popolazioni di Albania, Bosnia \& Herzegovina, Croazia, Francia, Grecia, Italia, Montenegro e Serbia, identificate con Dichoropetalum schottii. Differisce dall'affine D. carvifolium-chabraei per i raggi glabri dell'ombrella, i petali bianchi (non gialli), gli stili corti e canali secretori solitari nelle vallecole del frutto.

Parole chiave: Anatomia, Dichoropetalum, micromorfologia, nomenclatura, Peucedanum.

\footnotetext{
${ }^{1}$ Botanical Garden, Lomonosov Moscow State University, Russian Federation

E-mail: ostroumovata@gmail.com

${ }^{2}$ Scuola di Bioscienze e Medicina Veterinaria, Università di Camerino - Centro Ricerche Floristiche dell'Appennino, Parco Nazionale del Gran Sasso e Monti della Laga, S. Colombo, 67021 Barisciano (AQ), Italia

E-mail: fabio.conti@unicam.it

${ }^{3}$ Department of Botany and Plant Biotechnology, University of Johannesburg, P.O. Box 524, Auckland Park, 2006 Johannesburg, South Africa

E-mail: pmtilney@uj.ac.za

*Corresponding author: kljuykov@gmail.com

(C) 2015 Eugene V. Kljuykov, Tatiana A. Ostroumova, Fabio Conti, Patricia M. Tilney
}

Received: 28 August 2015

Accepted for publication: 12 October 2015

\section{INTRODUCTION}

The genus Dichoropetalum, described by Fenzl (1842), had for a long time been neglected, and was only recently reinstated (Pimenov et al., 2007). It now contains 38 species from eastern, western and southern Europe, North Africa and Southwestern Asia, the centre of diversity being Turkey. A few local Mediterranean endemics and two widespread species, D. schottii (Bess.) Pimenov \& Kljuykov and D. carvifolium-chabraei (Crantz) Soldano, Galasso $\&$ Banfi, have been reported for Europe, their range partly overlapping but with $D$. schottii growing further south than $D$. carvifolium-chabraei. The latter had been known under the name Peucedanum carvifolia Vill. nom. illeg. The nomenclatural problem was solved by Soldano et al. (2005) and Banfi et al. (2011). However, for D. schottii, some questions remained unanswered. The species was described as Peucedanum schottii by Besser (Candolle, 1830), based on a herbarium specimen of a plant originally cultivated in Cremenets. The geographic provenance of the plant material was unknown, being specified in the description as Vohlynia et Podolia (now Ukraine). In subsequent "Floras" (e.g., Thellung, 1925; Shishkin, 1951; Tutin, 1968; Hartvig, 1986), Ukraine was mentioned as part of the distribution area of $D$. schottii. However, D. schottii has never been collected in natural habitats in Ukraine or neighbouring countries, its distribution being limited to South Europe, from Serbia to France. In Vohlynia and Podolia, only D. carvifolium-chabraei is present. Vinogradova (2004) in "Flora of Eastern Europe" placed Peucedanum schottii in synonymy with $P$. carvifolium. In addition, $P$. schotti was described as a plant having flowers with ochroleucous petals whereas the petals are pure white in the South European species, and yellowish or greenish in D. carvifoliumchabraei. Thus there is uncertainty as to whether the Peucedanum schottii type specimens are identical to the South European species. If the type belongs to $D$. carvifolium-chabraei, the South European species should be given a new name. The lectotype in G-DC was designated by Hartvig (1986); the isolectotype with the label "Cult. Crem. Besser" is in LE (Vinogradova, 2003). 


\section{MATERIALS AND METHODS}

We have examined the photo of the lectotype in G-DC, the isolectotype of $P$. schottii in LE, visited its natural habitats in Italy and Montenegro, and studied numerous herbarium sheets in LE, MW, FL and BP (acronyms follow Thiers, continuously updated). We have also analyzed fruit anatomy and micro-morphology in D. schottii and D. carvifolium-chabraei.

\section{RESULTS}

\section{Type specimens of Peucedanum schottii}

The lectotype of Peucedanum schottii in G-DC is presented by leaf fragments and some mature fruits with solitary secretory ducts in valleculas and long styles. The isolectotype of Peucedanum schottii (Fig. 1) in LE was collected at the stage of flowers and young fruits,

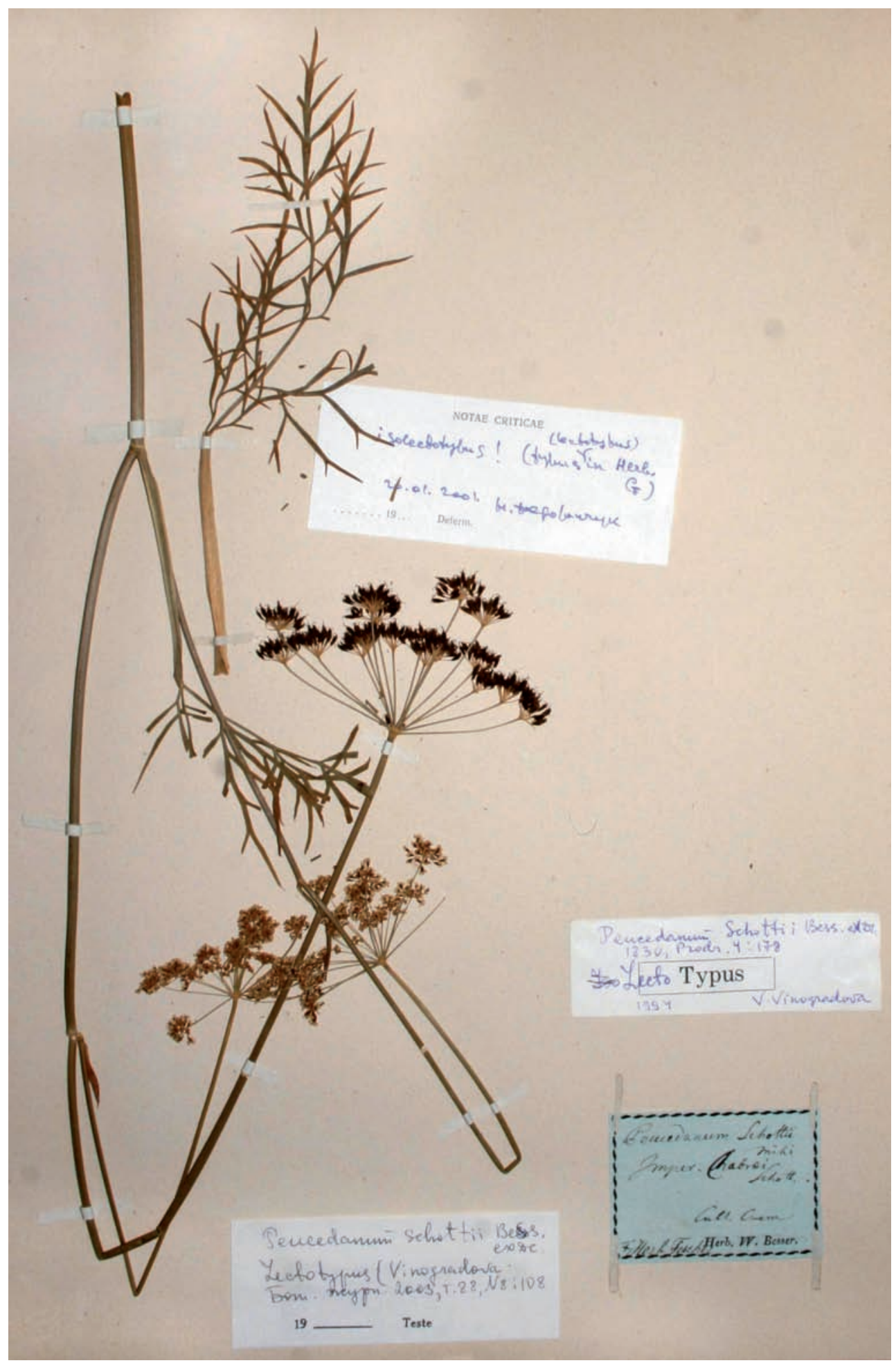

Fig. 1 - Isolectotype of Peucedanum schottii (LE). 
without roots. Besser mentioned the following in the protologue: "terete stems, pinnate leaves with narrow linear segments, no involucelle bracts, glabrous umbel rays, solitary vallecular secretory ducts and light-yellow petals". In our anatomical cross sections of young fruits, we confirmed the presence of solitary secretory ducts. Stem, leaf, umbel and fruit characters of the type specimens match those of the South European species occurring in natural populations. Besser may have described the petal colour of a dried herbarium specimen because the fresh petals are white. We have noticed that when dried, the white petals of $D$. schottii become yellowish. The natural populations are therefore identical to the type specimens of $P$. schottii.

Fruit morphology, anatomy and micromorphology of Dichoropetalum carvifolium-chabraei and D. schottii

Morphology and anatomy (Figs. 2-4): fruits separate into mericarps; elliptic; with carpophore bifid to the base; mericarps homomorphic; glabrous; strongly compressed dorsally; dorsal ribs filiform; marginal ribs narrowly winged; calyx teeth obsolete; stylopodia conical; styles recurved; exocarp cells small; commissure broad, exocarp interrupted near edges of marginal ribs; inner fibrous mesocarp present; mesocarp parenchyma not lignified dorsally but with lignified pitted walls in marginal ribs; vascular bundles compact; situated in primary rib bases; vittae vallecular and commissural; rib secretory ducts small or large, present in all ribs; endocarp not lignified; endosperm flat, slightly convex or slightly concave on commissural side; embryo with two cotyledons.

\section{Micromorphology (Fig. 5)}

On dorsal ribs cell borders indistinct, surface smooth or undulate, on valleculae and marginal ribs cell borders indistinct or slightly distinct, cells arranged at random, isodiametric, anticlinal walls straight, raised, outer periclinal walls slightly concave, cuticula striate or sparsely striate with straight striae; stomata few, cuticula around stomata smooth. Epicuticular secretions scanty, as thin discontinous layer.

Diagnostic characters are listed in Tab. 1.

\section{DISCUSSION}

The type specimen of Peucedanum schottii was cultivated from seed, presumably originally collected in South Europe. It is identical to natural populations, and the name Dichoropetalum schottii clearly applies to the South European species. Dichoropetalum carvifolium-chabraei and D. schottii have similar underground organs and are very much alike in habit. The petals, pure white in $D$. schottii, and greenish-yellowish in D. carvifolium-chabraei, become yellowish when dried. There are, however, several reliable diagnostic characters (Tab. 1) that enable us to regard the two plants as separate species.

\section{Taxonomy}

Dichoropetalum carvifolium-chabraei (Crantz) Soldano, Galasso \& Banfi, Atti Soc. it. Sci. nat. Museo civ. Stor. nat. Milano, 152(II): 89. $2011 \equiv$ Selinum carvifolium-chabraei Crantz, Inst. Rei Herb., 2: 126. 1766 三 Seseli carvifolia L. Sp. Pl.: 260. 1753, p.p. (excl. syn. Rivin.); L. Sp. Pl. ed. II: 350. 1762, p.
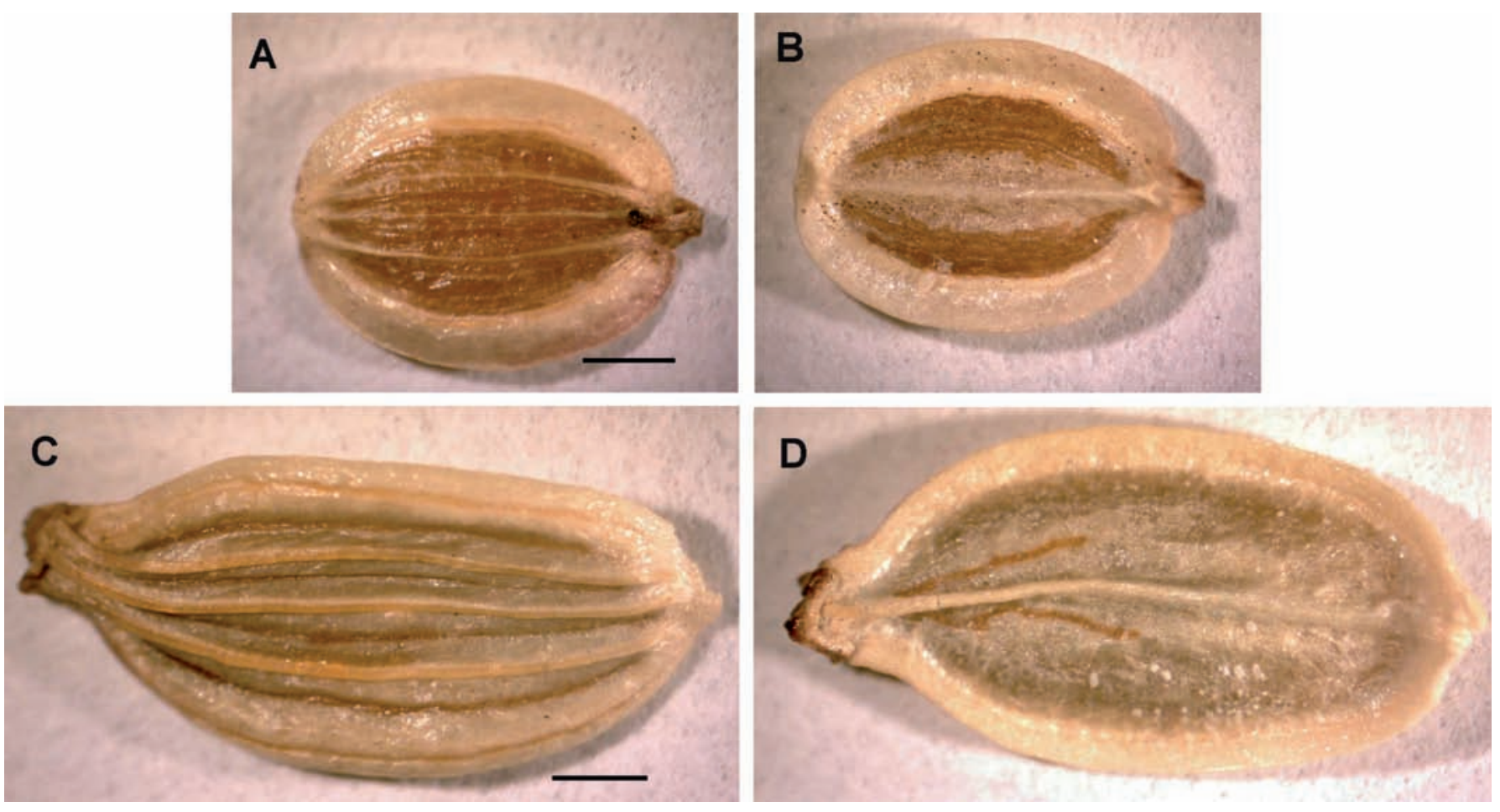

Fig. 2 - Mericarps. A, B) Dichoropetalum carvifolium-chabraei; C, D) D. schottii; A, C) dorsal side; B, D) commissural side. Scale bars $=1 \mathrm{~mm}$. 


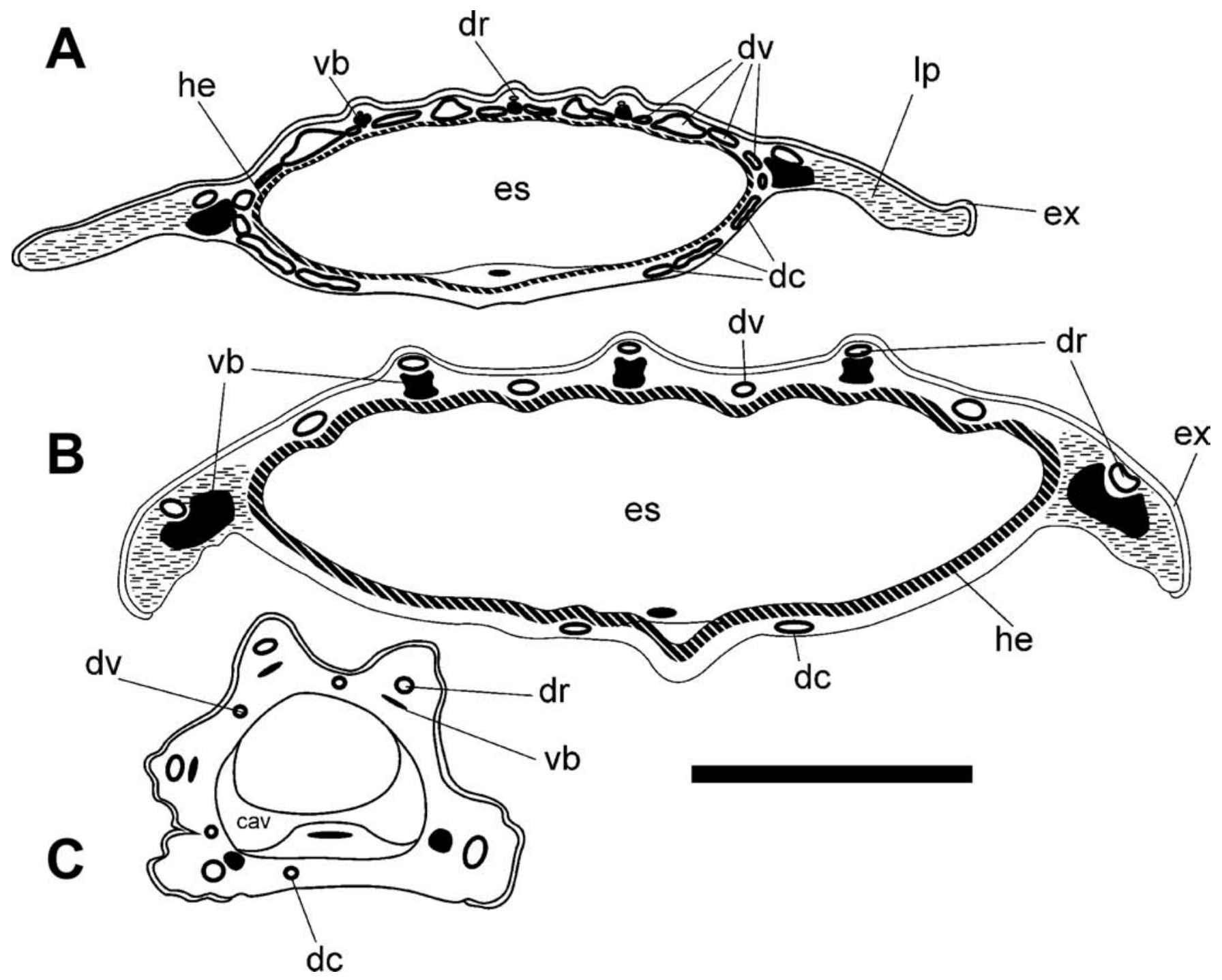

Fig. 3 - Mericarp transections, schematic. A) mature mericarp of Dichoropetalum carvifolium-chabraei, B) mature mericarp of $D$. schottii; C) immature mericarp of isolectotype of D. schottii. Scale bar $=1 \mathrm{~mm}$.

Abbreviations: cav) cavity, dc) commissural secretory duct, dr) rib secretory duct, dv) vallecular secretory duct, es) endosperm, ex) exocarp, he) hypendocarp, lp) lignified pitted parenchyma, vb) vascular bundle.
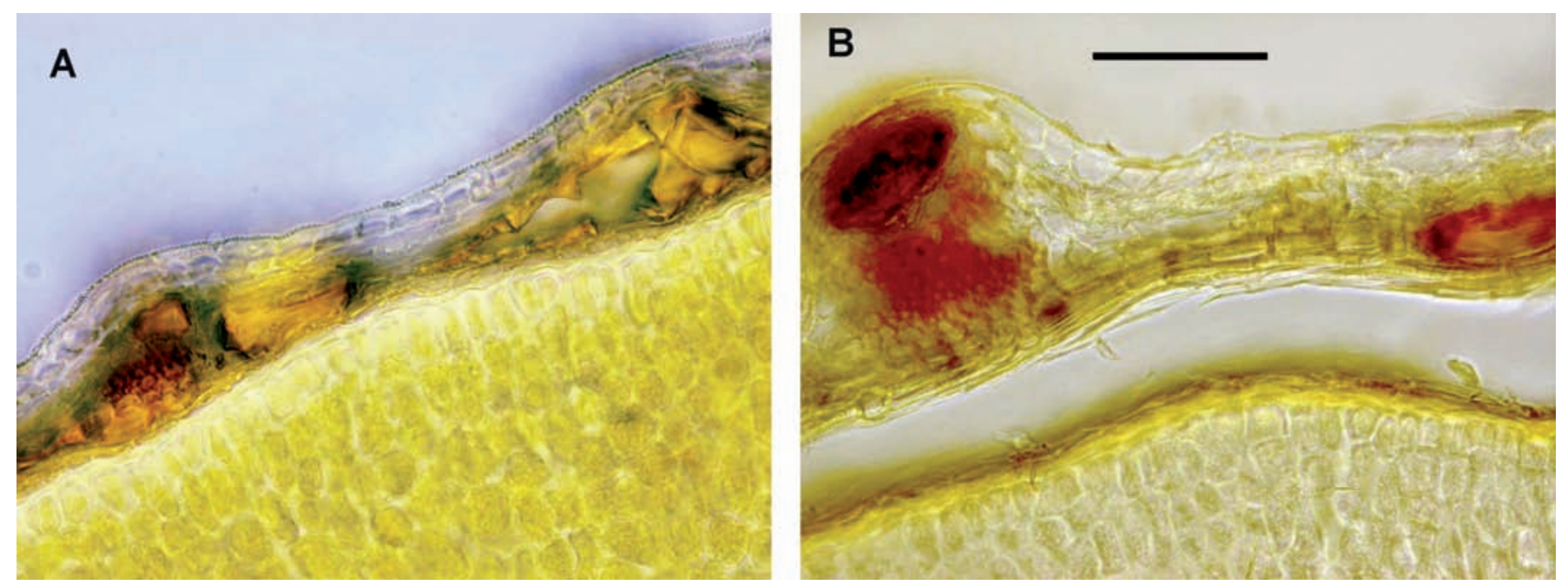

Fig. 4 - Microphotographs of mericarp transections. A) Dichoropetalum carvifolium-chabraei; B) D. schottii. Scale bar $=0.1 \mathrm{~mm}$. 

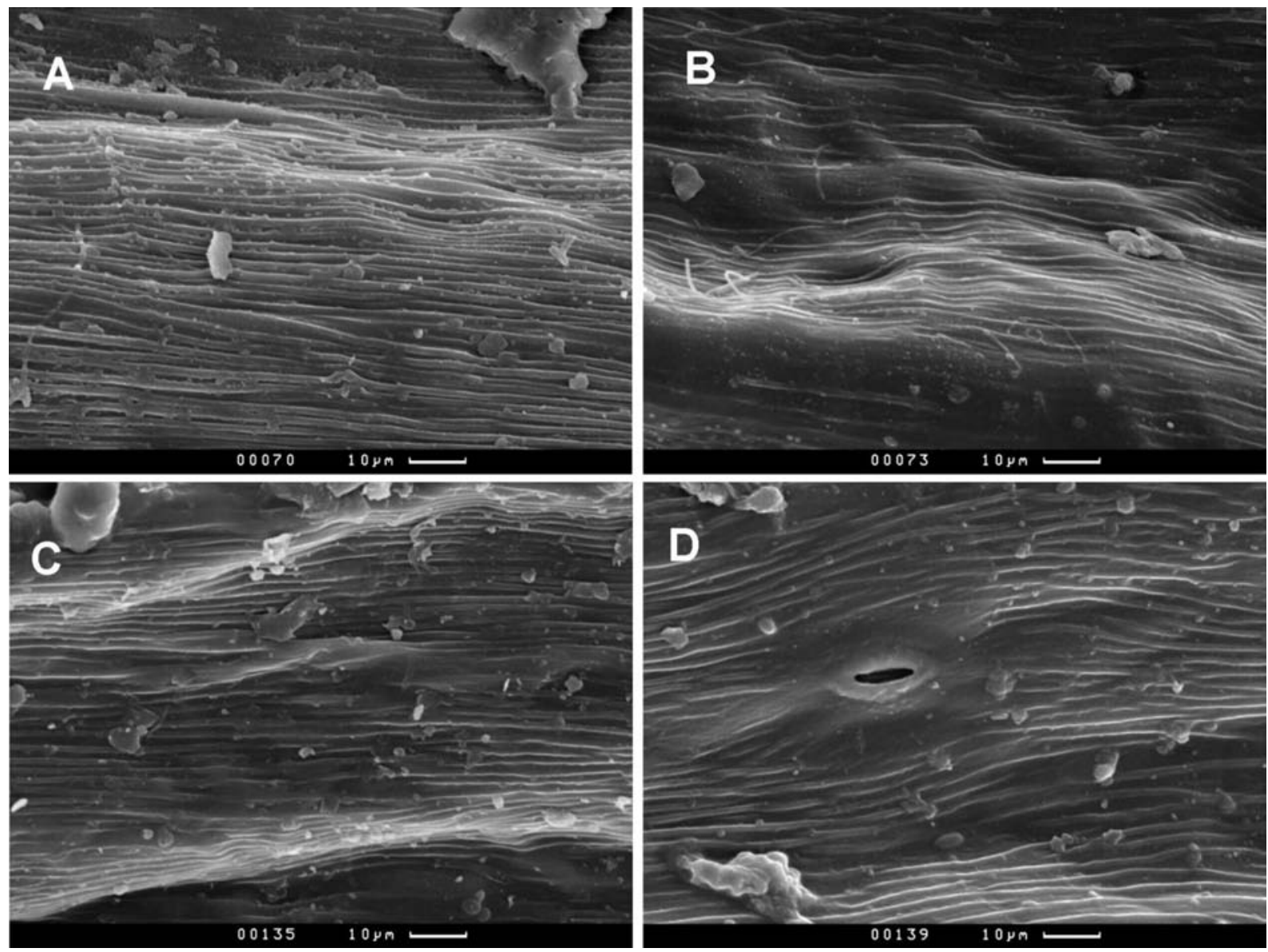

Fig. 5 - Fruit micromorphology. Mericarps. A, B) Dichoropetalum carvifolium-chabraei; C, D) D. schottii; A, C) dorsal rib; B, D) vallecula.

Tab. 1 - Diagnostic characters of Dichoropetalum carvifolium-chabraei and D. schottii.

\begin{tabular}{|l|l|l|}
\hline Character & D. carvifolium-chabraei & D. schottii \\
\hline Umbel rays & Scabrous & Glabrous \\
\hline Petal colour & Yellowish or greenish & White when fresh, yellowish when dry \\
\hline Style length & $\begin{array}{l}\text { Short, ca. 1 mm, slightly longer than } \\
\text { stylopodium }\end{array}$ & $\begin{array}{l}\text { Long, ca. 2 mm, 2-3 times longer than } \\
\text { stylopodium }\end{array}$ \\
\hline Fruit length, mm & $4-5$ & $5-7.5$ \\
\hline Fruit width, mm & $2.5-3.5$ & $4-6$ \\
\hline Vallecular secretory ducts & Several & Solitary \\
\hline Rib secretory ducts & Small & Small to large \\
\hline
\end{tabular}

min. p. $\equiv$ Peucedanum carvifolia Vill., Prosp. Hist. P1. Dauphiné: 25. 1779 [\& Hist. Pl. Dauphiné 2: 638. 1787] nom. illeg. $\equiv$ Dichoropetalum carvifolia Pimenov \& Kljuykov, Willdenowia, 37, 2: 478. 2007 nom. illeg. $\equiv$ Selinum chabraei Jacq., Fl. Austriac. 5: 72.1778 [\& in Murray, Syst. Veg., ed. 14: 279. 1784] nom. illeg. Lectotype (designated by Frey 1989: 280): [icon] Selinum carvifolia-chabraei Crantz, Stirp. Austr. Fasc. 3, t. 3, fig. 2. 1767.
= Selinum podolicum Bess., Prim. Fl. Galic. 2: 392. $1809 \equiv$ Peucedanum podolicum (Bess.) Eichw., Naturhist. Skizze: 155.1830

= Peucedanum euphimiae Kotov, Ukrainsk. Bot. Zhurn. 1, 2: 278. 1940. Holotype: "Inter frutices in decliviis calcareis et cretaceis in parte orientali Ucrainae" (KW).

Distribution. - Austria, Belgium, Bosnia \& Herzegovina, Bulgaria, Czech Rep., Croatia, France, Germany, 
Hungary, Italy, Luxembourg, Moldavia, the Netherlands, Romania, Russia, Serbia, Slovakia, Spain, Switzerland, Ukraine.

Dichoropetalum schottii (Bess.) Pimenov \& Kljuykov, Willdenowia, 37, 2: 480. 2007 三 Peucedanum schottii Bess. in Candolle, Prodr. 4: 178. 1830. Lectotype (designated by Hartvig 1986): G-DC!; isolectotype "Cult. Crem. Besser" (Vinogradova 2003) (LE!).

= Peucedanum petraeum W.D.J.Koch, Syn. Fl. Germ., ed. 1: $304.1837 \equiv$ Peucedanum schottii var. petraeum W.D.J.Koch, Syn. Fl. Germ., ed. 2: 334. 1843 三 Peucedanum schottii subvar. petraeum (W.D.J.Koch) Burnat, Fl. Alp. Marit. 4: 206. 1906. - Holotype: Italia "In rupibus et locis asperis saxosis (zwischen Triest $\mathrm{u}$. Fiume an Felsen der neuen Straße), Noe" (W; isotype: G).

Distribution. - Albania, Bosnia \& Herzegovina, Croatia, France, Greece, Italy, Montenegro, Serbia.

The main synonyms are mentioned here; for the full list of synonyms see Pimenov et al. (2007).

\section{Acknowledgements}

This work is supported by grants from the Russian Foundation for Basic Research (No 13-04-00648 and 1529-02748). We are grateful to the curators of BP, FL, LE, MW herbaria for use of their facilities. We thank Laurent Gautier (G) for providing us the image of the lectotype of Peucedanum schottii. SEM studies are performed at the User Facilities Center of M.V.Lomonosov Moscow State University under financial support of Ministry of Education and Science of Russian Federation.

\section{REFERENCES}

Banfi E., Galasso G. \& Soldano A., 2011 - Notes on systematics and taxonomy for the Italian vascular flora. 2. Atti della Società Italiana di Scienze naturali e del Museo civico di Storia naturale di Milano, 152 (2): 85-106.

Candolle de A.P., 1830 - Prodromus Systematis Naturalis Regni Vegetabilis. V. 4. Sumptibus Sociorum Treuttel et Würtz, Paris.

Fenzl E., 1842 - Pugillus plantarum novarum Syriae et Tauri occidentalis primus. Wien.

Hartvig P., 1986 - Umbelliferae. In: Mountain flora of Greece. Strid A. \& Tan K. (eds.). Cambridge University Press, Cambridge, 1: 655-735.

Pimenov M.G., Kljuykov E.V. \& Ostroumova T.A., 2007 Critical taxonomic analysis of Dichoropetalum, Johrenia, Zeravschania and related genera of UmbelliferaeApioideae-Peucedaneae. Willdenowia 37: 465-502. doi:10.3372/wi.37.37208

Shishkin B.K., 1951 - Peucedanum. In: Flora SSSR. Shishkin B.K. \& Bobrov E.G. (eds.). Editio Academiae Scientiarum URSS, Moskva \& Leningrad, 17: 168-203.

Soldano A., Conti F., Banfi E. \& Galasso G., 2005 - Nomenclatural novelties (Novità nomenclaturali). In: An Annotated Checklist of the Italian Vascular Flora. Conti F., Abbate G., Alessandrini A. \& Blasi C (eds.). Palombi Editori, Roma: 17-22; 27-32.
Thellung A., 1925-26 - Umbelliferae. In: Illustrierte Flora von Mittel-Europa. Hegi G. (ed.). Blackwell Wissenschafts-Verlag, München, 5 (2): 926-1537.

Thiers B., 2014 - Index herbariorum: a global directory of public herbaria and associated staff. New York Botanical Garden's Virtual Herbarium. <http://sweetgum. nybg.org/ih/> (retrieved on October 2015).

Tutin T.G., 1968 - Umbelliferae. In: Flora europaea. Tutin T.G., Heywood V.H., Burges N.A., Moore D.M., Valentine D.H., Walters S.M. \& Webb D.A. (eds.). Cambridge University Press, Cambridge, 2: 315-375.

Vinogradova V.M., 2003 - Type specimens of Apiaceae taxa from the East Europe kept in the herbarium of Komarov Botanical Institute (LE). Bot. Zhurn. (St. Petersburg), 88 (8): 105-111.

Vinogradova V.M., 2004 - Apiaceae Lindl. In: Flore Europae orientalis. Tsvelev N.N. (ed.). KMK, MoscowSanct-Petersburg, 11: 315-437. 